\title{
Haiku - transkulturowo
}

Adam Dziadek 


\section{Haiku - transkulturowo}

Adam Dziadek

TEKSTY DRUGIE 2017, NR 4, S. 152-158

DOI: $10.18318 /$ td.2017.4.9

$\mathbf{Z}$ agadnienia genologii literackiej nie cieszą się w ostatnich latach nadmiernym zainteresowaniem. Śmiało można by nawet powiedzieć, że odstawione zostały na boczny tor współczesnych badań literaturoznawczych. Tym bardziej cieszyć musi pojawienie się pracy, która ten gatunek literacki stawia w samym centrum zainteresowania. Chodzi o znakomite, w moim odczuciu, studium napisane przez Beatę Śniecikowską, zatytułowane Haiku po polsku. Genologia w perspektywie transkulturowe' ' i opublikowane w serii „Monografie Fundacji na Rzecz Nauki Polskiej".

Znaczenie tej pracy dla literaturoznawstwa opiera się na co najmniej trzech ważnych faktach. Po pierwsze, jest to monografia bardzo szeroko omawiająca obecność haiku w polskiej literaturze i kulturze - autorka

1 B. Śniecikowska Haiku po polsku. Genologia w perspektywie transkulturowej, "Monografie Fundacji na Rzecz Nauki Polskiej”, Wydawnictwo Naukowe Uniwersytetu Mikołaja Kopernika, Toruń 2016, s. 722.
Adam Dziadek - prof. dr hab., pracuje wUŚ. Autor książek Rytm i podmiot w liryce Jarosława Iwaszkiewicza i Aleksandra Wata (1999), Obrazy i wiersze.ZZagadnień interferencji sztuk w polskiej poezji wspótczesnej (2004), Na marginesach lektury.

Szkice teoretyczne (2006). Ostatnio wydał Projekt krytyki somatycznej (2014) oraz wspólnie z Janem Zielińskim Notatniki Aleksandra Wata (2015). Tłumacz prac R. Barthes'a, J. Derridy, J.-L. Nancy, M. Augé i innych. Członek redakcji „Pamiętnika Literackiego". Kontakt: adam_dziadek@ wp.pl 
nie ogranicza swoich badań do samej tylko literatury, ale wykracza daleko poza nią, analizuje przy tym rozmaite prace edytorskie, typograficzne, a także dzieła sztuki, które nawiązują do tej słynnej japońskiej formy wierszowej. Nikt w Polsce przed Śniecikowską nie napisał tak obszernej monografii na temat haiku i związków tego gatunku ze sztukami wizualnymi. Jest to praca całkowicie pionierska, która omawia różnorodne uwikłania poezji polskiej w tradycję haiku na przestrzeni przeszło stu lat. Po drugie, książka zawiera też oryginalną propozycję teoretyczną w postaci genologicznych badań transkulturowych. Podstawy metodologiczne tej pracy są zróżnicowane - to sprawa dosyć oczywista, ponieważ tego domaga się sam jej przedmiot. Śniecikowska opiera swój projekt badań genologicznych przede wszystkim na pojęciu transkulturowości (tu rzecz jasna odwołanie przede wszystkim do prac Wolfganga Welscha, ale też Ewy Rewers, która uznaje przestrzeń transkulturową za miejsce spotkania, interferencji wartości i norm różnych kultur) i łączy go z komparatystyką oraz silnie z nią związaną kategorią modalności. Choć sama "transkulturowość" budzi wiele dyskusji i nie do końca jest w Polsce oswojona - badaczka ma pełną tego świadomość - to jednak związane z nią idee, wybrane głównie z prac Welscha i włączone do projektu genologicznego, sprawdzają się w tym systemie bardzo dobrze: transkulturowość nie jako uniformizacja, a jako wytwarzanie nowej różnorodności; występuje ona na makropoziomie całych społeczności, ale też na mikropoziomie tożsamości indywidualnej; tożsamość transkulturowa wiąże się z kosmopolityzmem, ale też zawiera afiliację lokalną, siła wielkich dzieł nie ogranicza się jedynie do kontekstu kulturowego, w którym one powstały. Idąc tropem Włodzimierza Boleckiego, badaczka wychodzi z założenia, że haiku można analizować w perspektywie recepcji oraz w perspektywie „modalności kultury” - modalność jako kategoria, która zmusza czytelnika do uznania obecności podmiotu w tekście wypowiedzi (s. 78). Jeszcze innym punktem metodologicznego umocowania jest "mikrologia” (prace Aleksandra Nawareckiego jak i piszącego te słowa), która umożliwia badania form miniaturowych (takie właśnie są haiku), a także mikroanalizy stylistycznych - jak pisze autorka - „drobin” zawartych $\mathrm{w}$ tych formach. Ta praktyka mikrologiczna rozprzestrzenia się niemal na całą książkę i sprawia, że dokonywane przez badaczkę analizy są niezwykle interesujące i odkrywcze. Szczególnie ciekawe są według mnie analizy struktur brzmieniowych wpisanych zarówno w teksty obcojęzyczne, jak i w polskie, co nie może dziwić, ponieważ badaczka jest w tym zakresie znakomitym ekspertem, o czym dobitnie świadczą jej wcześniejsze prace ( $H a-$ iku po polsku jest kontynuacją i zarazem rozwinięciem jej dotychczasowych 
poszukiwań2). Poza historią i teorią literatury oraz teorią kultury badaczkę zajmują również zagadnienia translatologii i estetyki.

Po trzecie, praca ta jest udaną - jak myślę - próbą stworzenia metajęzyka umożliwiającego komparatystyczny, a także interdyscyplinarny opis badanych zjawisk. Nie mam wątpliwości, że wypracowane w niej narzędzia będą pomocne w genologicznych badaniach nad tekstami literackimi powiązanymi ze sztukami wizualnymi. Zresztą może nie tylko, bo teoretyczne podstawy tej pracy mogłyby umożliwić też badania nad tekstami literackimi powiązanymi z muzyką - myślę np. o sonecie i jego związkach z muzyką klasyczną (np.Vivaldi, który opisuje swoje Cztery pory roku za pomocą czterech sonetów), nie tylko dawną, ale i współczesną, czy z muzyką popową.

Przy tak określonych ramach metodologicznych książka ta włącza się również w badania nad literaturą polskiego i zachodniego modernizmu, wpisując się wyraźnie w obszar badań komparatystyki kulturowej. Zgodnie z zamierzeniami autorki jej praca nie ma być jedynie opisem stanu - jak to sama nazywa za Piotrem Michałowskim - „transplantologii genologicznej”, ale ma też powiedzieć jak najwięcej na temat polskiej poezji i powiązanych z nią sztukach wizualnych w XX i XXI wieku. I rzeczywiście mówi. Haiku w ujęciu zachodnim jest gatunkiem, który odegrał wielką rolę w przemianach poezji modernistycznej - to także jedno z założeń tej pracy, które zostaje rozwinięte i w pełni uzasadnione.

Śniecikowska chętnie wchodzi w polemikę z badaczami, którzy zajmowali się wcześniej twórczością m.in. Marii Pawlikowskiej-Jasnorzewskiej (imponujące jest zestawienie jej miniatur z twórczością Amy Lowell, Richarda Aldingtona i japońskimi tankami), Czesława Miłosza (dostrzegano już związki jego poezji z haiku i kulturą japońską, ale nikt wcześniej tak gruntownie tego zagadnienia nie opracował), Stanisława Grochowiaka (jego Haiku-images zostały tu poddane wszechstronnej analizie) czy Mirona Białoszewskiego (analizy wierszy w kontekście haiku, senryū i koanów), Urszuli Kozioł, Ryszarda Krynickiego i innych - weryfikując stanowiska wielu badaczy, autorka dokonuje nowych, czasami zaskakujących odczytań dzieł tych poetów.

2 Zob. B. Śniecikowska Słowo - obraz - dźwięk. Literatura i sztuki wizualne w koncepcjach polskiej awangardy 1918-1939, Universitas, Kraków 2005, a także B. Śniecikowska, „Nuż w uhu"? Koncepcje dźwięku w poezji polskiego futuryzmu, "Monografie Fundacji na Rzecz Nauki Polskiej”, Wydawnictwo Uniwersytetu Wrocławskiego, Wrocław 2008.

3 P. Michałowski Polskie imitacje haiku, w: Polska genologia. Gatunek w literaturze współczesnej, red. R. Cudak, Wydawnictwo Naukowe PWN, Warszawa 2009, s. 166. 
Z innej strony przygląda się uważnie również - jeśli mogę je tak określić - „popowym haiku” w wykonaniu Dariusza Brzóski-Brzóskiewicza, których autorka nie ocenia zbyt wysoko i określa nawet jako "antyhaiku”, a także tak niezwykłemu fenomenowi, z którego istnienia niewielu czytelników zdaje sobie sprawę, jak „haiku ortodoksyjnie chrześcijańskie” (chodzi o „ubrane” - dosyć zresztą nieporadnie - w formę haiku teksty m.in. Hieronima Stanisława Kreisa, Krzysztofa Agamsa, Dariusza Piaska; przetwarzanie tekstów biblijnych, co widać w niektórych podanych tu przykładach, wydaje się kompletnie pozbawione sensu i w ogóle nie wynika z zagadnień czysto religijnych, uwikłania klasycznych haiku w buddyzm czy szintoizm).

Przyglądam się uważnie tej rozprawie i raczej się nie mylę, twierdząc, że Śniecikowska przeczytała na temat haiku niemal wszystko, co zastało napisane (w bibliografii nie ma co prawda prac wydanych po japońsku, ale są prace pisane przez Japończyków i wydane po angielsku) - dotyczy to bardzo obszernej światowej literatury przedmiotu traktującej o tym gatunku, tekstów literackich (zarówno polskich, jak i obcojęzycznych, co pozwala na przeprowadzenie świetnych analiz porównawczych z dziełami takich pisarzy jak choćby Jack Kerouac czy E.E. Cummings), ale też portali internetowych, których, z racji ogromnego w świecie zainteresowania tą japońską formą, jest bardzo wiele. Jeśli chodzi o dobór tekstów literackich stanowiących podstawę materiału badawczego, jest to poezja polska od Młodej Polski aż po teksty najnowsze. Badaczka zestawia je nie tylko z klasycznymi haiku japońskimi (wraz z ich kontekstem estetycznym, religijnym i etycznym), ale też z powiązanymi z haiku utworami poetów amerykańskich, angielskich, francuskich, hiszpańskich czy wreszcie meksykańskich pisanymi w XX wieku. Sporo miejsca poświęca także analizom XX-wiecznych polskich przekładów haiku - uznaje je, bardzo słusznie, za istotny probierz modernistycznych przemian literatury.

Całość rozważań zawartych w tym obszernym studium jest osadzona w szerokim kontekście kulturowym, religijnym i lingwistycznym (wstępne partie książki). Jest to jak najbardziej uzasadnione postępowanie, które pozwala odejść od licznych stereotypów pojawiających się w wielu pracach literaturoznawczych i kulturoznawczych, które - jak słusznie twierdzi autorka - przyczyniają się często do rozmycia konturów „niezmiernie zdyscyplinowanej" (s. 95) sztuki haiku.

Próbując określić genologiczne ramy zachodnich (ale i polskich) haiku, Śniecikowska sięga po pojęcie prototypu (chodzi o prototypowe modelowanie gatunku - w tej sprawie autorka odwołuje się do prac Bożeny Witosz czy 
Romy Sendyki - a także inwariantny model gatunku). Sam gatunek (haiku) jest tu również traktowany jako pojęcie typologiczne (tu odwołania do prac Anny Wierzbickiej, Dirka de Geesta, Hendrika van Gorpa), które nie wymaga jednorodności wszystkich analizowanych tekstów. Zdecydowana większość utworów wybranych przez badaczkę do analizy ma prototypowe cechy gatunku (są one tu określane również jako „haikemy"). Prototypowe modelowanie gatunku umożliwia autorce szerokie diagnozowanie polskiej poezji modernistycznej, która na różne sposoby zbliża się do haiku. Lista podstawowych wyznaczników haiku zachodniego w ujęciu prototypowym jest bardzo interesująca, chodzi tu m.in. o zwięzłość (najczęściej układy trzywersowe), rezygnację z silnej, bezpośredniej ekspozycji emocji podmiotu lirycznego, sensualność (układy sensualne, które zdaniem autorki mają kluczowe znaczenie zarówno w haiku klasycznych, jak i w haiku zachodnich; to właśnie dlatego niezwykle ważna staje się w tej pracy propriocepcja, a więc poczucie ciała w przestrzeni - to sprawa szczególnie ważna, która w dotychczasowych badaniach nad haiku była często pomijana lub omawiana marginalnie), oszczędne użycie środków stylistycznych (sposób ich wykorzystania wiąże się m.in. z empatią, łagodnym humorem, stosowaniem obrazowych kireji). Te omówione przeze mnie w największym skrócie wyznaczniki stają się podstawą do opisu haiku w zachodniej literaturze modernistycznej.

W ostatniej, siódmej, części książki podjęty zostaje problem, jak to określa celnie autorka, „logowizualności haiku” - jest to ujęcie na wskroś komparatystyczne. Punktem wyjścia jest kultura japońska, zwłaszcza związek z formami plastycznymi (kaligrafia, różne rodzaje tradycyjnego malarstwa oraz ekfrastyczność), a ciekawe analizy, bogato ilustrowane reprodukcjami i zdjęciami, dotyczą tekstów poetyckich, a także malarstwa, grafiki, typografii artystycznej, wystaw muzealnych i wreszcie twórczości wideo. Zawarte w tej części rozważania prowadzą do pytania o „logowizualność transkulturową", o to, czy jest ona możliwa. Okazuje się, że jak najbardziej tak i że takie formy jak haiku, haiga, haibun mogą do pewnego stopnia stać się polskie. Wskazując na jeden z najważniejszych łączników między tradycjami (również w ujęciu transkulturowym), Śniecikowska zaznacza, że pozostaje nim „samo silne dążenie do zespalania słowa i obrazu, przekraczania i zacierania granic sztuk. W japońskim uniwersum kulturowym jest ono zaszczepione bardzo głęboko, poparte m.in. wielowiekowymi praktykami kaligrafów czy malarzy sumi-e, w kulturze Okcydentu natomiast wyraźnie nasiliło się w dobie nowoczesności" (s. 641). Trudno nie zgodzić się z tak zarysowanym i przekonującym stanowiskiem, tym bardziej że takie podejście pozwala dostrzec 
podobieństwa między nowoczesną sztuką Zachodu i japońskimi praktykami artystycznymi.

Trochę po macoszemu potraktowano w tej pracy teksty Rolanda Barthes'a poświęcone haiku. W podrozdziale zatytułowanym Poetyka haiku, haiku a senryū czytamy: „Niektóre z zachodnich omówień poetyki haiku brzmią intrygująco, dowodzą wielkiej fascynacji japońskimi miniaturami, nie niosą jednak weryfikowalnych wskazówek dla badaczy literatury i relacji transkulturowych" (s. 70), dalej następują cytaty z Imperium znaków. Oczywiście, że Barthes pisze intrygująco, jego lektura Japonii (nawet jeśli traktuje ją jak tekst do przeczytania, nawet jeśli Japonia Barthes'a wyłania się z jego fantazmatów) wyrasta z semiotyki podpartej psychoanalizą. Kiedy Barthes pisał tę książkę pod koniec lat 6o. (ukazała się po raz pierwszy w roku 1970), nie mógł nic wiedzieć na temat transkulturowości. Myślę zupełnie odwrotnie niż Śniecikowska: uważam, że we fragmentach Imperium znaków poświęconych haiku jest mnóstwo wskazówek dla badaczy relacji transkulturowych - chodzi tu przede wszystkim o sensualność i propriocepcję, na które badaczka zwraca szczególną uwagę w swoim studium. Metafory, za pomocą których Barthes buduje swój tekst, wprowadzają niezwykle bogatą sferę doznań cielesnych i zmysłowych. Myślę, że Barthes jak mało kto wyczuwał japońską cielesność i jej obecność zarówno w życiu codziennym, jak i w sztuce. Z innej strony autorka potrafiła docenić mało znane prace Barthes'a na temat haiku zawarte w jego La préparation du roman I et II. Cours et séminaires au Collège de France 4 . Są one znakomite, a haiku jest tu jednym z najważniejszych gatunków zestawianych z modernistyczną literaturą francuską, zwłaszcza zaś z dziełami Prousta.

Z całą pewnością Haiku po polsku. Genologia w perspektywie transkulturowej jest najważniejszą książką na temat obecności haiku w polskiej literaturze i sztuce, jaka dotąd się ukazała. Co więcej, jest to książka, po którą będzie musiał sięgnąć każdy, kto zechce zajmować się tym niezwykłym, znanym na całym świecie japońskim gatunkiem literackim. Książka ta zawiera oryginalną propozycję nowoczesnych badań genologicznych - chodzi mi o genologię transkulturową, która z całą pewnością stanie się źródłem wielu inspiracji dla badaczy zainteresowanych tym obszarem wiedzy literaturoznawczej. Wszystko wskazuje na to, że w przyszłych badaniach genologicznych nie będzie można pominąć propozycji w niej zawartych.

4 R. Barthes La préparation du roman I et II. Cours et séminaires au Collège de France (1978-1979 et 1979-1980, texte établi, annoté et présenté par N. Léger, Seuil/IMEC, Paris 2003. 


\section{Abstract}

\section{Adam Dziadek}

UNIVERSITY OF SILESIA (KATOWICE)

The Haiku in a Transcultural Way

Review: B. Śniecikowska, Haiku po polsku: Genologia w perspektywie transkulturowej [The Haiku in Polish: Genealogy from a Transcultural Perspective], FNP, Toruń 2016

\section{Keywords}

haiku, haiku in Poland, transcultural genre studies, cultural comparative studies 